\title{
LOW TEMPERATURE WASTEWATER TREATMENT AND RECYCLING BY PSYCHROPHILIC BIODEGRADATION (A CASE STUDY MEXICO)
}

\author{
Sánchez-Góngora M.-A., Peón-Escalante I.-E., Cardona-Juárez T., Ortega-Arroyo L., Castaño V. M. \\ НИЗКОТЕМПЕРАТУРНАЯ ОЧИСТКА И РЕЦИРКУЛЯЦИЯ СТОЧНЫХ \\ ВОД ПОСРЕДСТВОМ ПСИХРОФИЛЬНОЙ БИОДЕГРАДАЦИИ \\ (НА ПРИМЕРЕ МЕКСИКИ)
}

Санчез-Гонгора М.-А., Пеон-Эскаланте И.-Э., Кардона-Хуарез Т., Ортега-Арройо Л., Кастано В. М.

\begin{abstract}
Introduction. Only $27 \%$ of the surface water in Mexico complies with the local BOD5 and COD standards. Constant desertification of the soils contributing to reduced recharge rate of the aquifers makes finding a solution to effective and wide-spread wastewater treatment a very pressing matter. The paper provides experimental data on a case study of low temperature wastewater treatment. Methods. We treated domestic (sanitary) wastewater in a continuous flow anaerobic biodigester and conducted its physicochemical evaluation during winter-spring. The treatment was done by means of a low temperature process and with a supplied influent flow volume of $20.78 \mathrm{~L} /$ day. Results. The first sludge formation in the initial stage showed substantial changes compared to those obtained in the final stage, where the effluent had scarce lime as a result of the microbiological activity. This transformation is seen through a removal of: $99.9 \%$ of settleable solids (SS), $92.66 \%$ of total solids (TS), $99.14 \%$ of total suspended solids (TSS), 33.21 \% of 5-d biochemical oxygen demand (BOD $)$, $3.64 \%$ of chemical oxygen demand (COD) with a steady $\mathrm{pH}$ oscillating between 8.12 and 8.72 , electric conductivity (EC) within the range from $1961 \mu \mathrm{S} / \mathrm{cm}$ to $1785 \mu \mathrm{S} / \mathrm{cm}$, temperature from 19.2 to $20.1{ }^{\circ} \mathrm{C}$ in the effluent. Conclusion. Thus, the system described is considered to be stable, easy and economic meeting the current conditions for the unloading of treated wastewater suited for agricultural reuse according to NOM-001-ECOL-1996 standard.
\end{abstract}

Keywords: permissible maximum range, lime, psychrophilic biodegradation, removal, resilience, life cycle metaphor

\begin{abstract}
Аннотация
Введение. Лишь 27 \% поверхностных вод в Мексике соответствует нормативам по БПК и ХПК. На фоне прогрессирующего опустынивания и сокращения подпитки водоносных горизонтов проблема поиска эффективного и широкодоступного метода очистки сточных вод в стране стоит очень остро. В работе представлен эксперимент по низкотемпературной очистке сточных вод. Методы. Физико-химическая оценка бытовых сточных вод (санитарных), обработанных в проточном биореакторе, проводилась посредством низкотемпературного процесса с расходом 20,78 л/день притока в зимне-весенний период. Результаты. Первый ил, образовавшийся в начальной фазе, продемонстрировал существенные изменения в своих характеристиках по сравнению с илом, полученным на конечной стадии, где стоки имели мало извести в результате микробиологической активности. Изменение отразилось в удалении: 99,9 \% осаждаемого вещества (SS), 92,66 \% общих твердых веществ (ST), 99,14 \% общих взвешенных веществ (SST), 33,21 \% биологического потребления кислорода (БПК ), 3,64 \% химического потребления кислорода (ХПК) при стабильном рН от 8,12 до 8,72, электропроводности (ЭП) в диапазоне от 1961 мкСм/см до 1785 мкСм/см, температуре от 19,2 до $20,1^{\circ} \mathrm{C}$ в сточных водах. Заключение. Таким образом, можно считать предложенную систему очистки стабильной, простой и экономичной. Она отвечает текущим требованиям для сброса очищенных сточных вод, пригодных для повторного использования в сельском хозяйстве, указанным в стандарте NOM-001-ECOL-1996. Ключевые слова: максимально допустимый предел, известь, психрофильная биодеградация, удаление, устойчивость, метафора жизненного цикла.
\end{abstract}

\section{Introduction}

The global weather change facilitates desertification of the soils, reducing recharge rate of aquifers while the rates of the evapotranspiration increase. This process results in rising fluctuations in the quantity and quality of the water available for consumption.
In Mexico, this problem is especially acute since $64 \%$ of the water supply is extracted from underground sources; the agricultural sector consumes $77 \%$ of the extracted water from both surface and underground sources to irrigate 25 million hectares (85 irrigation districts and 
39 thousand irrigation units), distributed in rural areas. However, the analysis of the $\mathrm{BOD}_{5}$ and the COD shows that only $27 \%$ of the surface water in Mexico has acceptable quality, while the remaining $73 \%$ is polluted [40].

Regardless of the fact, the locals - including women, most affected by polluted water - still opt to consume water from any source available, exposing themselves to naturally and/or anthropogenically contaminated water. The anthropogenic type of contamination generates municipal and industrial wastewater, $60 \%$ of which remains untreated. At the same time, the communities continue to survive with agriculture activities using regionals resources only during their productive working days, which still requires significant volumes of water [40]. As water is gradually becoming an increasingly restricted resource, it seems beneficial to utilize the "Life Cycle Metaphor" while analysing waste management systems for it provides a comprehensive view of the processes and impacts involved: quality of the water treated to reuse the effluent in the next life cycle, waste management options, etc. [11].

The previous points can be developed by identifying and studying the following indicators of poverty: water availability, migration, income, food security, health and marginalization of poor communities [37] to present the metaphor whose systemic perspective [11] offers diverse opportunities of adopting eco-technologies focused on the recovery of treated water and its organic nutrients [23].

The latter can be very useful for farmers, who have found it necessary to seek mitigation alternatives to the problem of water scarcity and lack of sewerage, usually resorting to irrigation with residual water from the discharges.

The foregoing has led to propose multiple alternatives, some oriented to areas of limited resources with population not exceeding 100-200 families. Anaerobic biodigesters could help address the problems of these localities. As treatment of water for reuse for agricultural purposes is the main objective, therefore, these digesters must have the following characteristics in design and construction: low cost, self-construction, simple operation and easy maintenance.

The distinctive features are integrated within the following conditions: small volume, reduced site, high efficiency of purification based on volume, oxygen supply in the natural environment, operative flexibility, feasible scaling, simple design [2] and low energy consumption [8].

The mentioned basic principles must comply with the following variables of the anaerobic process: organic load velocity, biomass production, rate of utilization of the soil, hydraulic retention time (HRT), which is reduced if simpler compounds such as sugar are used, solid retention time (SRT), start up, microbial metabolism, ambient factors, configuration of the reactor [24], which propitiates the formation of micro-niches were different organisms will grow [19].

Meeting these requirements will favour a satisfactory development of the anaerobic process with low biomass production [20], at thermophilic and psychrophilic temperatures [19], in a dark environment, without dissolved oxygen or its precursors. The abovementioned conditions trigger biochemical reactions induced by diverse groups of microorganisms, which degrade the organic matter in sequential order. They transform complex macromolecules into low molecular weight compounds (methane, carbon dioxide, water and ammonia) using such electron receptors as $\mathrm{CO}_{2}$, $\mathrm{SO}_{4}, \mathrm{NO}_{3}-, \mathrm{Fe}$ and $\mathrm{Mo}$, in order to have available electrons released during the degradation of organic matter [24].

Therefore, the efficiency of a biodigester of real scale is evaluated according to the following parameters: removal of settleable solids (SS), of total solids (TS), of total suspended solids (TSS), also of 5-d biochemical oxygen demand $\left(\mathrm{BOD}_{5}\right)$, of chemical oxygen demand (COD), $\mathrm{pH}$, electric conductivity (EC), temperature and heavy metals in the effluent.

\section{Materials and Methods}

This experiment consisted of two simultaneous stages: field research with samplings and evaluation in the laboratory.

The study required an installation of a prototype on a real scale for real time function in a space provided by a research centre located at the northwestern side of Mexico City. A rectangular-shaped biodigester had four chambers inside to carry out the process with the operation volume of $1 \mathrm{~m}^{3}$ (Fig. 1). We used ferrocement for the structure, and applied homogeneous natural polymer solution for waterproofing. 
In this low-temperature digester, the flow is horizontally displaced by the principle of communicating vessels, so that the amount of water inflow equals to water outflow.

When the construction of the biodigester was complete, we proceeded to sampling according to the proposed experimental design.

\subsection{Samplings}

Once the biodigester load was complete, the experiment stage started as the sampling points or ports were previously set and can be found through the paper such as: chamber, inflow stage or inflow compartment (C-i) and/or chamber, outflow stage or compartment (C-e).

In those sites simple samplings were done as established in NOM-AA-003-1980 three times per week in a fixed morning schedule until finishing a sample of 50 repetitions with the following determinations: $\mathrm{T}\left({ }^{\circ} \mathrm{C}\right), \mathrm{SS}$, TSS, TS, EC, $\mathrm{pH}$, total hardness. Each sample was analysed triple fold except for two parameters: SS and $\mathrm{T}\left({ }^{\circ} \mathrm{C}\right)$. In both variables, the measurement was only taken once along the monitoring.

The study was completed by doing other basic determinations for the process control and surveillance, such as: $\mathrm{BOD}_{5}, \mathrm{COD}$, as well as heavy metals that require compound samplings for those tests.

The determinations mentioned in the paragraphs above were mainly chosen according to the current standard (NOM-001-ECOL-1996), to be completed with some of NOM-CCA/32. Both documents establish standards and maximum permissible ranges of usable treated water for agricultural watering. It is vital to highlight the analysis of results was undertaken by using average values of the statistical study for analysis and standards observation.

\subsection{Analytical techniques}

The applied specific methods for evaluating the chosen standards followed the official Mexican standards suited for each determination.

$\mathrm{T}\left({ }^{\circ} \mathrm{C}\right)$ water measurement was done at the sampling site, with a TC-2 diameter glass mercury thermometer (Taylor brand, range from -20 to $110^{\circ} \mathrm{C}$, series: 6332). A $100 \mathrm{~mL}$ water sample was taken in the inflow and outflow of the process based on the method (NMX-AA-007-SCFI-2000 and APHA, AWWA, 1995).

In regard to SS, it was necessary to obtain a sample of $1 \mathrm{~L}$, as shown by the technique of sedimentation in Cones Imhoff (NMX-AA-004-SCFI-2013) by doing the cone reading.

Meanwhile TSS and TS were quantified by following the procedure described in NMX-AA-034SCFI-2001, using two types of equipment: muffle (Lindberg/Blue brand, 625 model, N51H-365397 series, range from $64-1100{ }^{\circ} \mathrm{C}$ ) and furnace (Felisa brand, FE292-A model, 0810003 series, range from $\left.5-250{ }^{\circ} \mathrm{C}\right)$.

The EC analysis required the collection of a 500 $\mathrm{mL}$ sample of the so far mentioned points. From the volume obtained, a sample was taken to analyse

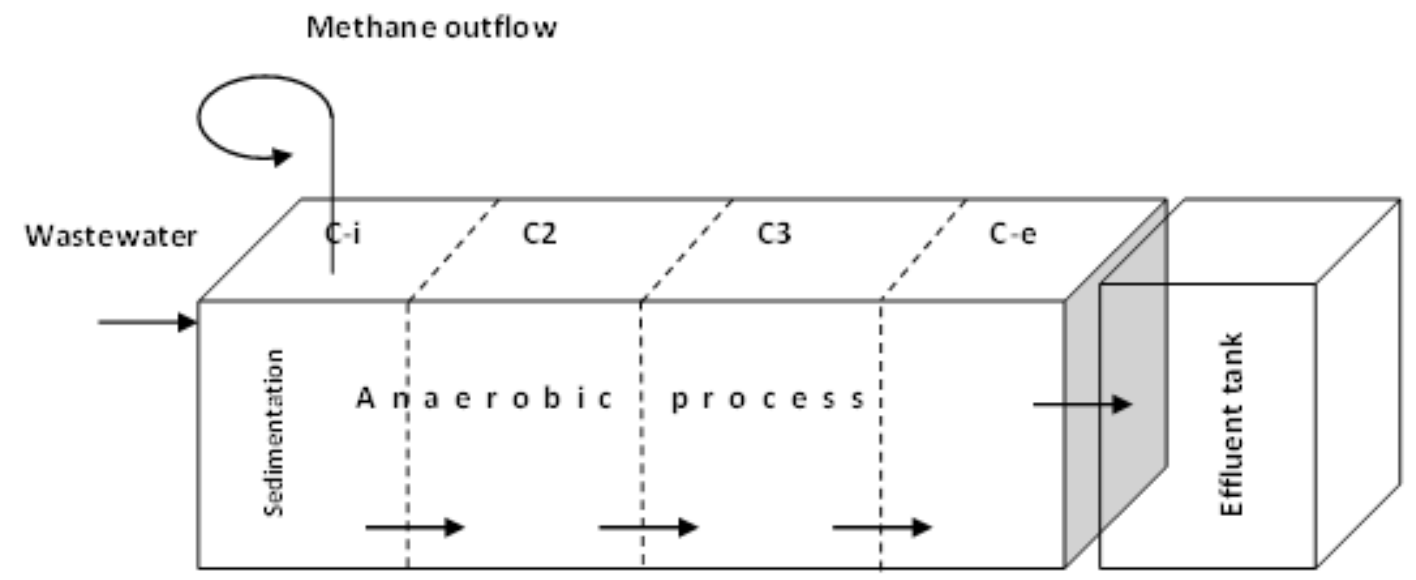

Fig. 1. Four-chambered rectangular biodigester. The influent under treatment is submitted by precipitation on the $\mathrm{C}$-i upper side wall. Inside, the liquid horizontally flows out through the lower part of the compartments. The effluent derived from $\mathrm{C}$-e is retrieved to be stored recovery in an outer collector 
the variable, using a conductivity measurement equipment (Conductronic brand, PC18 model, 322 series, range from 1-999.9 $\mu \mathrm{S} / \mathrm{cm} ; 1-99.99 \mu \mathrm{S} / \mathrm{cm}$, with a $0.1 \mu \mathrm{S} / \mathrm{cm}$ accuracy) based on the standard method (NMX-AA-093-SCFI-2000 and APHA, AWWA, 1995).

Meanwhile the $\mathrm{pH}$ measurements were practiced as appointed by the Mexican standard (NMX-AA008-SCFI-2011 and APHA, AWWA, 1995). C-i and $\mathrm{C}$-e port aliquots were employed measuring the $\mathrm{pH}$ with regard to room temperature, using a $\mathrm{pH}$ meter (pH-Meter, CONDUCTRONIC brand, PC18 model, $0-14 \pm 0.02$ range) gauged with $\mathrm{pH}$ Buffer solutions within the range between 7.00 and 10.00 (J.T. BAKER brand).

The $\mathrm{BOD}_{5}$ test followed the NMX-AA-028SCIF-2001 procedure using an incubator (Mermmert brand, IPP 500 model, R5100300 series, range from $\left.0-40{ }^{\circ} \mathrm{C}\right)$.

The COD determination was made in accordance with NMX-AA-030/1-SCFI-2012.

The total hardness analysis was made by using the technique described in NMX-AA-072-SCFI-2001.

The sampling characterization was concluded with the determination of heavy metals, covering the procedure appointed by NMX-AA-051-SCFI-2001, by using an Atomic Absorption spectrophotometer, ("Fast Sequential Atomic AA240FS" model, Varian brand), and employing the flame techniques and formation of hydrides with the accessory (Sample
Introduction Pump System, Agilent Technologies brand).

\section{Results and discussion}

The decision to carry out simple samplings of $\mathrm{C}-\mathrm{i}$ influent and effluent of $\mathrm{C}$-e contained in the biodigester is due to two aspects: the caudal supply during the day is low, and the type of sampling that offers in-detail aspects of the process at that very moment, as well as of its composition.

Thus, the simple sampling was applied to the following parameters: $\mathrm{T}\left({ }^{\circ} \mathrm{C}\right), \mathrm{SS}, \mathrm{TS}, \mathrm{TSS}, \mathrm{EC}, \mathrm{pH}$, and Total Hardness in order to gather data which was subjected to statistical analysis obtaining: statistical mean, standard deviation, variation coefficient, percent coefficient of variation, mode, maximum, minimum, average, and variance see (Table 1). These measurements were completed with adjusted graphics using the models of Lorentz or Gauss, accordingly. For each graphic settings are shown in blue while the experimental data is in black.

The statistical data in (Table 1) helped to study the process behaviour and to decide if the calculated average concentrations are within the permissible maximum limits for treated water reuse, as stipulated by NOM-001-ECOL-1999, currently in effect.

With both values (Table 2) was structured and its data is completed with parameters chosen from NOM-CCA/32-ECOL-1993, which was replaced by the standard previously mentioned. Nonetheless, they are considered as basic variables for the

Table 1

Statistical results of the samplings taken from the biodigester's influent-effluent

\begin{tabular}{|c|c|c|c|c|c|c|c|c|c|c|}
\hline & & $\begin{array}{l}\text { Statistical } \\
\text { mean. }\end{array}$ & $S D$ & $V C(\%)$ & $V C$ & Mode & Maximum & Minimum & Average & Variance \\
\hline \multirow[t]{2}{*}{$\mathbf{T}\left({ }^{\circ} \mathbf{C}\right)$} & $\mathrm{C}-\mathrm{i}$ & 18.24 & 1.684 & 8.75 & 0.087 & 21.3 & 21.7 & 16.0 & 19.2 & 2.780 \\
\hline & C-e & 19.14 & 1.816 & 9.02 & 0.090 & 21.2 & 23.6 & 16.30 & 20.1 & 3.232 \\
\hline \multirow[t]{2}{*}{$\mathrm{SS}(\mathrm{ml} / \mathrm{L})$} & $\mathrm{C}-\mathrm{i}$ & 143.5 & 95.550 & 66.11 & 0.661 & 100.0 & 450 & 36.0 & 144.5 & - \\
\hline & C-e & 0.1 & 0.069 & - & - & 0.0 & 0.4 & 0.0 & 0.02 & 0.005 \\
\hline \multirow{2}{*}{$\begin{array}{l}\text { TS } \\
(\mathrm{mg} / \mathrm{L})\end{array}$} & $\mathrm{C}-\mathrm{i}$ & 10616.01 & 7190.58 & 67.73 & 0.6773 & - & 41278.75 & 597.50 & 9871.02 & - \\
\hline & C-e & 746.70 & 225.76 & 30.23 & 0.3023 & 872.5 & 998.33 & 115.67 & 694.30 & - \\
\hline \multirow{2}{*}{$\begin{array}{l}\text { TSS } \\
(\mathrm{mg} / \mathrm{L})\end{array}$} & $\mathrm{C}-\mathrm{i}$ & 10219.11 & 7145.14 & 69.91 & 0.6991 & - & 41278.75 & 797.50 & 10036.62 & - \\
\hline & C-e & 87.44 & 50.12 & 57.32 & 0.5732 & 63.33 & 317.50 & 10.00 & 85.88 & - \\
\hline \multirow[t]{2}{*}{ pH } & $\mathrm{C}-\mathrm{i}$ & 7.82 & 0.3400 & 4.3458 & 0.0434 & 7.50 & 8.53 & 7.05 & 8.12 & 0.1141 \\
\hline & C-e & 8.45 & 0.2198 & 2.6003 & 0.0260 & 8.50 & 8.73 & 7.92 & 8.78 & 0.0477 \\
\hline \multirow[t]{2}{*}{ EC } & $\mathrm{C}-\mathrm{i}$ & 1968.13 & 385.69 & 19.41 & 0.1941 & 2200 & 2260 & 908 & 1961 & - \\
\hline & C-e & 1757.82 & 318.04 & 18.09 & 0.1809 & 2220 & 2440 & 678 & 1735 & - \\
\hline \multirow[t]{2}{*}{ TH } & $\mathrm{C}-\mathrm{i}$ & 199.55 & 37.71 & 18.89 & 0.1889 & 232.08 & 247.67 & 92.61 & 194.16 & - \\
\hline & C-e & 208.87 & 20.75 & 9.706 & 0.0970 & 229.59 & 246.51 & 146.88 & 203.23 & - \\
\hline
\end{tabular}

Inflow chamber (C-i), Outflow chamber (C-e), Total hardness (T. H mg/L) 
Table 2

\section{Comparison between the effluent process results and the maximum permissible limit for concentrations according to current standards}

\begin{tabular}{|c|c|c|c|c|c|c|}
\hline Parameter & $\begin{array}{c}\text { Concentration } \\
\text { obtained }\end{array}$ & $\begin{array}{l}\text { NOM-001- } \\
\text { ECOL-1999 }\end{array}$ & N. $C$ & I. $C$ & $\begin{array}{c}\text { Meets NOM-001- } \\
\text { ECOL-1999 y/o } \\
\text { NOM-CCA/032-193 }\end{array}$ & $\begin{array}{c}\text { I. } C \\
\text { Present in the effluent }\end{array}$ \\
\hline $\mathbf{T}\left({ }^{\circ} \mathbf{C}\right)$ & 20 & 40 & & & Affirmative & \\
\hline SS & 0.0 & 2 & & & Affirmative & \\
\hline SST & 85.38 & 200 & & & Affirmative & \\
\hline $\mathbf{C E}$ & 1735 & $2000^{*}$ & & & & \\
\hline \multicolumn{7}{|l|}{ DT } \\
\hline BOD $_{5}$ & 148.1 & 150 & & & Affirmative & \\
\hline pH & 8.1 & $5.5-10.00$ & & & Affirmative & \\
\hline As & 0.00145 & 0.4 & & & Affirmative & \\
\hline Cd & 0.1826 & 0.4 & & $>150$ & Affirmative & \\
\hline $\mathrm{Cn}^{-}$ & $<0.0395$ & 3.0 & & & Affirmative & \\
\hline $\mathrm{Cu}$ & 0.1240 & 6.0 & & $>40$ & Affirmative & Negative \\
\hline $\mathbf{H g}$ & 0.0005 & 0.02 & & & & \\
\hline $\mathrm{Ni}$ & 0.1240 & 4 & $0.006-0.5$ & $>10$ & Affirmative & Negative \\
\hline $\mathbf{P b}$ & 0.2000 & 1 & $0.02-200$ & $>300$ & Affirmative & Negative \\
\hline Zn & 0.5549 & 20 & & $>150$ & Affirmative & Negative \\
\hline
\end{tabular}

* Parameter considered as value reference by NOM-CCA/032-ECOL/1993, which sets maximum permissible limits for pollutants in urban or municipal wastewaters for agricultural watering use.

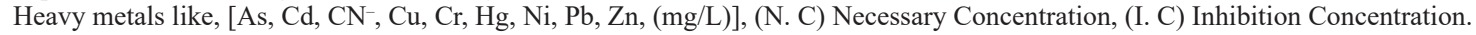

process control and the effluent's final destination, furthermore, these values show if the results content of heavy metals have an impact on the process or on the effluent.

Nevertheless, the compound samplings taken at a specific time schedule for the following determinations: $\mathrm{BOD}_{5}, \mathrm{COD}$ and heavy metals, were done triplicate obtaining a result used to estimate the sample size average value of the studied process.

\subsection{Temperature $\mathrm{T}\left({ }^{\circ} \mathrm{C}\right)$}

The temperature statistical results (Table 1) were analysed for $\mathrm{C}-\mathrm{i}$ influent and $\mathrm{C}$-e effluent as shown in-detail in figure (2a), where an open range can be seen between $17.15{ }^{\circ} \mathrm{C}$ and $21.98{ }^{\circ} \mathrm{C}$, this range reports 9 frequencies of 2 . While the only period of four was read at $21.4{ }^{\circ} \mathrm{C}$, and finally, two temperatures of $19.4{ }^{\circ} \mathrm{C}$ and $19.6^{\circ} \mathrm{C}$ at frequency three were registered.

Once the water process ended in this stage, this element continued flowing out through the biodigester to conclude its process at $\mathrm{C}$-e. The mathematic temperature values (Table 1) are in the open range from $17.86^{\circ} \mathrm{C}$ to $22.11^{\circ} \mathrm{C}$ figure (2b), where four distributions at two are reported, as well as three distributions with three frequencies at three among $18.2{ }^{\circ} \mathrm{C}, 20.7^{\circ} \mathrm{C}$ and $21.2{ }^{\circ} \mathrm{C}$.

The parameter monitoring in both compartments reported typical temperature ranges (Table 1) for a process of psychrophilic biodegradation, and shows an intensive microbial activity built up by diverse groups that do not affect either chemical reactions, reaction velocities or the oxygen concentration [7].

Besides the characteristics above, there are other typical peculiarities of the process of low temperatures: accumulation of suspended solids in sludge [9], incomplete granulation, methane genesis reduction, hydrolysis velocity reduction as well as nitrification, less gas production and a low COD removal [36]. However, the C-e effluent results are within the maximum permissible limit allowed by the concerned standard (Table 2).

\subsection{Settleable Solids $(S . S \mathrm{~mL} / \mathrm{L})$}

The SS form $60 \%$ of the suspended solids in wastewaters [7], where $1 / 3$ is organic matter, $1 / 3$ belongs to colloids and the last $1 / 3$ is composed by dissolved matter [41].

In this study, the solids come from intermittently supplied raw water estimated at $0.02013 \mathrm{~m}^{3} /$ day. 

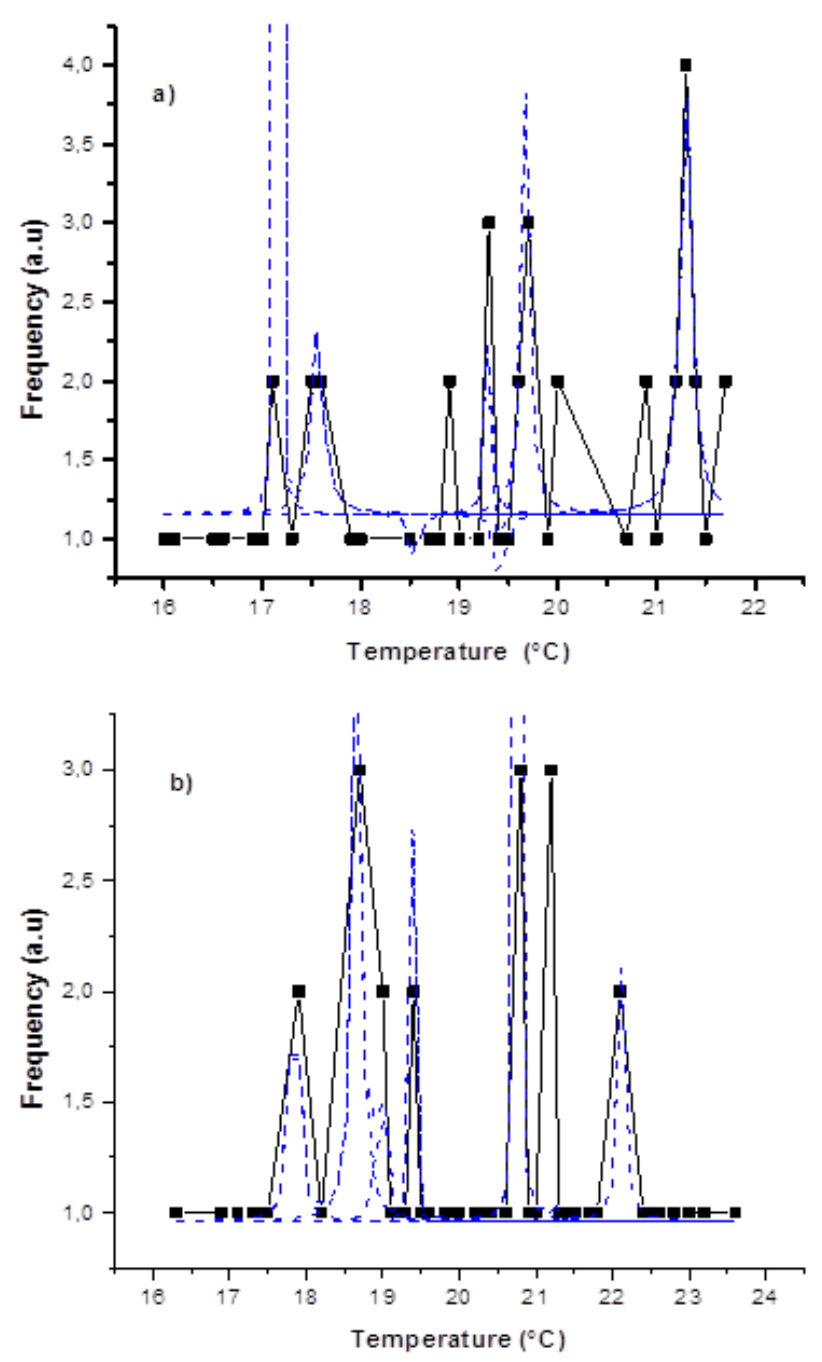

Fig. 2. C-i (a) temperature control record during a 50-day period exhibits oscillations within itself, whereas in C-e (b) more steadiness is seen in the variable due to a fewer number of frequencies or intensity. The ongoing line represents original values, and the dotted trace refers to adjustment

That volume of flow entered into $\mathrm{C}-\mathrm{i}$ by fall, building up soft brown - grey granulated sludge, with scarce intestinally disposed food remnants - not fully degraded. As a result, there is an organic and inorganic matter precipitation that compactly lies at the compartment bottom for meeting the function of sedimentation in $\mathrm{C}-\mathrm{i}$.

This SS followed rigorously the Imhoff cone technique outlined in the norm, where the reading was made in $\mathrm{mL} / \mathrm{L}$ for $\mathrm{C}-\mathrm{i}$ inflow and $\mathrm{C}$-e outflow. Regarding the earlier, the statistical measurements (Table 1) are completed in figure (3a), where it can be seen a narrow range with frequency values at three, including the two highest concentrations $151.52 \mathrm{~mL} / \mathrm{L}$ and $247.54 \mathrm{~mL} / \mathrm{L}$, and the lowest amounts from $45.55 \pm 2.51 \mathrm{~mL} / \mathrm{L}$ to $55.28 \pm 6.43 \mathrm{~mL} / \mathrm{L}$.

Here also, several concentrations registered at frequency two and with their crests and valleys among the frequencies one, two and three represent the microbiological life cycle in the process. This latter depends on the alkaline $\mathrm{pH}$ and the influent of low temperature, which represent two important variables for better organic matter biodegradability and sludge stability indication [43]. This sludge is formed from the organic load present in the supplied wastewater when the solid content clashes on the existing sludge so that it does not increase and remains older. In contrast, this early sludge supply applied to steady sludge as others in an ageing
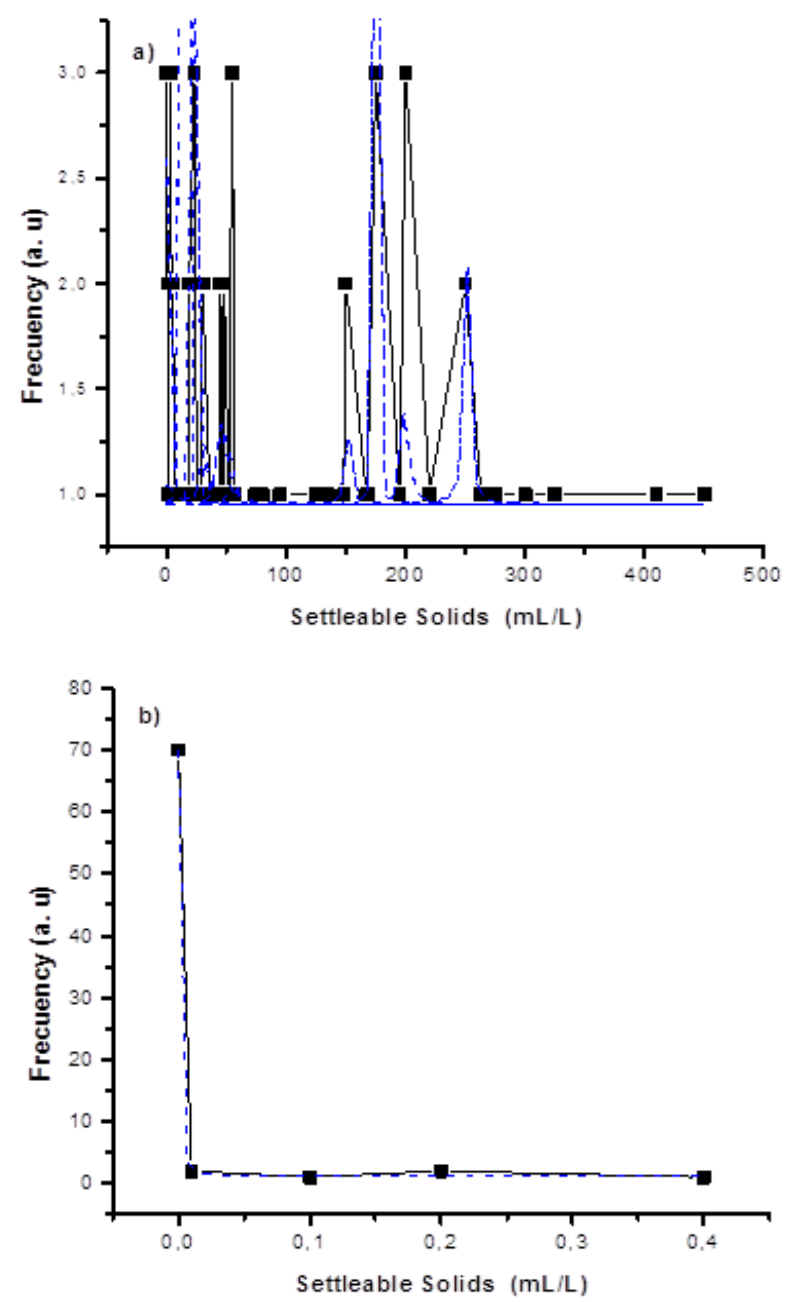

Fig. 3. Graphic (a) shows SS fluctuations in C-i during a 50-day period. In contrast to $\mathrm{C}$-e (b) SS are not seen, which exhibits removal efficiency 
process gives rise to special treatment sludge, which first increases and then diminishes according to the bacterial life cycle stage of the sampling day.

As soon as the digestion is completed in $\mathrm{C}-\mathrm{i}$, the treated water continues to flow until reaching C-e, where the SS concentration showed an important change of the statistical results (Table 1).

This information is verified in figure (3b), where the curve shows a frequency of 70 measurements with a value of $0 \mathrm{~mL} /$ of $\mathrm{SS}$ in C-e. The result represents a $100 \%$ removal - this percentage did not suffer any main changes during the experimentation stage. The highest reading was recorder at $0.04 \mathrm{~mL} / \mathrm{L}$.

The C-e effluent showed data with a maximum level of settling and degradation which improved the quality of the recovered water [35], without thick sediments, which were transformed as a result of biodegradation until getting a light grey sand lime, with an effluent slightly amber colour that meets the defined standard limit (Table 2) for the parameter.

\subsection{Total Suspended Solids (T.S.S mg/L)}

They are referred to as indexes to evaluate wastewater treatments [7]. In this case the analysed influent is composed by inert elements such as sand and clay by $20 \%$ and the remaining organic material by $80 \%$.

These solids are settled by precipitation depending on the size and density of particles, which can be fine with micro diameter [3], and when the biodigester is fed at a slow speed the TSS is further diminished [11], producing a clarified liquid.

The influent contained in $\mathrm{C}-\mathrm{i}$, with a lot of inert solids [38] and partially degraded organic materials build up a thick dark brown layer at the bottom of Gooch crucible, resulting from sedimentation and hydrolysis.

By finding TSS in $\mathrm{C}-\mathrm{i}$ and its determination drew statistical results (Table 1) completed with the interpretation of figure (4a), where the biggest number of events between $5000-15000 \mathrm{mg} / \mathrm{L}$ of concentration was reported. These amounts were dramatically changed when the biodegradation finished in C-e, and a low-solid effluent in Gooch crucible filter was obtained. The degraded solid particles are seen as scarce homogeneous sediments, lime and amber colour that suggest: fewer compartment dead spaces, different active sludge decantation content [36], and the resistance of organic crisis that allow the biodegradable solids to be degraded in microbial films [38].

These peculiarities lead to the effluent analysis in $\mathrm{C}$-e to find statistical data (Table 1), shown in curve (4b) identifying the bigger number of results in the range from $34.2740 \mathrm{mg} / \mathrm{L}$ to $78.6320 \mathrm{mg} / \mathrm{L}$. The range has four values with frequency at two as well as a periodical reading at three. When C-e values are compared to $\mathrm{C}-\mathrm{i}$, a dramatic fall by $99.14 \%$ of TSS was found, which can be explained as an efficient psychrophilic digestion process, so this parameter is within the maximum permissible limit of $120 \mathrm{mg} / \mathrm{L}$, appointed by NOM-CCA/032ECOL/1993 (Table 2).

\subsection{Total Solids (TS mg/L)}

The C-i influent's TS are composed by: organic matter, portions of fixed solids and volatile solids
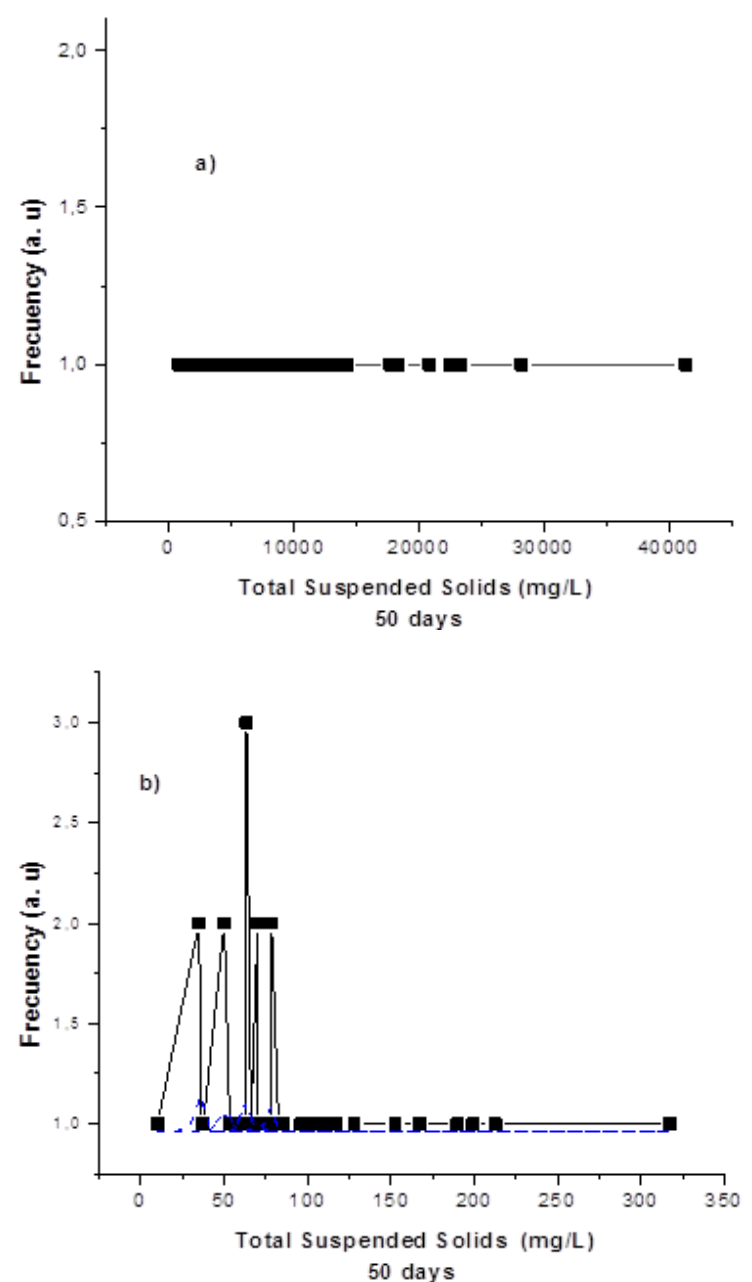

Fig. 4. The graphic (a) shows a linear behaviour in $\mathrm{C}-\mathrm{i}$ in a 50 -day period. In contrast to C-e (b), TSS variations within the greater number of values are recognized 
building up semi-degraded dark brown material. This colour was not altered while burning the sample inside the plain bottom crucible, which shows a biomass growth [36].

The compartment liquid was determined generating statistical values referred to in (Table 1). These values are completed with the interpretation of figure (5a) where the linear compartment shows a greater number of concentrations piled up in the range from $1000 \mathrm{mg} / \mathrm{L}$ to $15000 \mathrm{mg} / \mathrm{L}$, and the fewest number of reading was between $30000 \mathrm{mg} / \mathrm{L}$ and $40000 \mathrm{mg} / \mathrm{L}$.

Once the wastewater process in $\mathrm{C}-\mathrm{i}$ concluded, the water continues its path and treatment until reaching $\mathrm{C}-\mathrm{e}$, where the effluents follows the anaerobic digestion process, characterizing TS in: texture changes, amber colour - light brown-grey, lime consistency and a scarce amount of mud at the flat bottom crucible.

These features generated by the analytical tests offer statistical data in (Table 1), which are identified in figure (5b) where a frequency in two at $872.5001 \mathrm{mg} / \mathrm{L}$ is shown; placing the greatest number of readings between $745 \mathrm{mg} / \mathrm{L}$ and $950 \mathrm{mg} / \mathrm{L}$.

Those TS values in C-e represent a $92.66 \%$ fall compared to $\mathrm{C}-\mathrm{i}$ (Table 1), which is interpreted as a satisfactory material removal in the psychrophilic biodegradation.

The concentration of SS, TS and TSS were considered as basic parameters which show more than a $90 \%$ decrease. The qualitative features vary significantly between $\mathrm{C}-\mathrm{i}$ and $\mathrm{C}-\mathrm{e}$, as a consequence of the organic matter degradation.

\subsection{EC Dynamics $(\mu \mathrm{S} / \mathrm{cm})$}

This variable helps to know the salinity and the wastewater ionic strength of and treated water, indirectly. This is due to a bigger amount of ions or dissolved salts, a greater conductivity, which indicates that the ionic dynamic in the process is suitable for obtaining water for irrigation according to the normalized values [7, 21].

The EC influent drew the statistical measurements registered in (Table 1), at a $19.2{ }^{\circ} \mathrm{C}$ temperature and an $8.12 \mathrm{pH}$. This information is described in detail in figure (6a), where the greatest data grouping is located in a range of $1879.3-2372.2 \mu \mathrm{S} / \mathrm{cm}$. It is observed an only frequency of four events in $2198 \mu \mathrm{S} / \mathrm{cm}$, and five repetitions of two in the range of $1900-2400 \mu \mathrm{S} / \mathrm{cm}$.
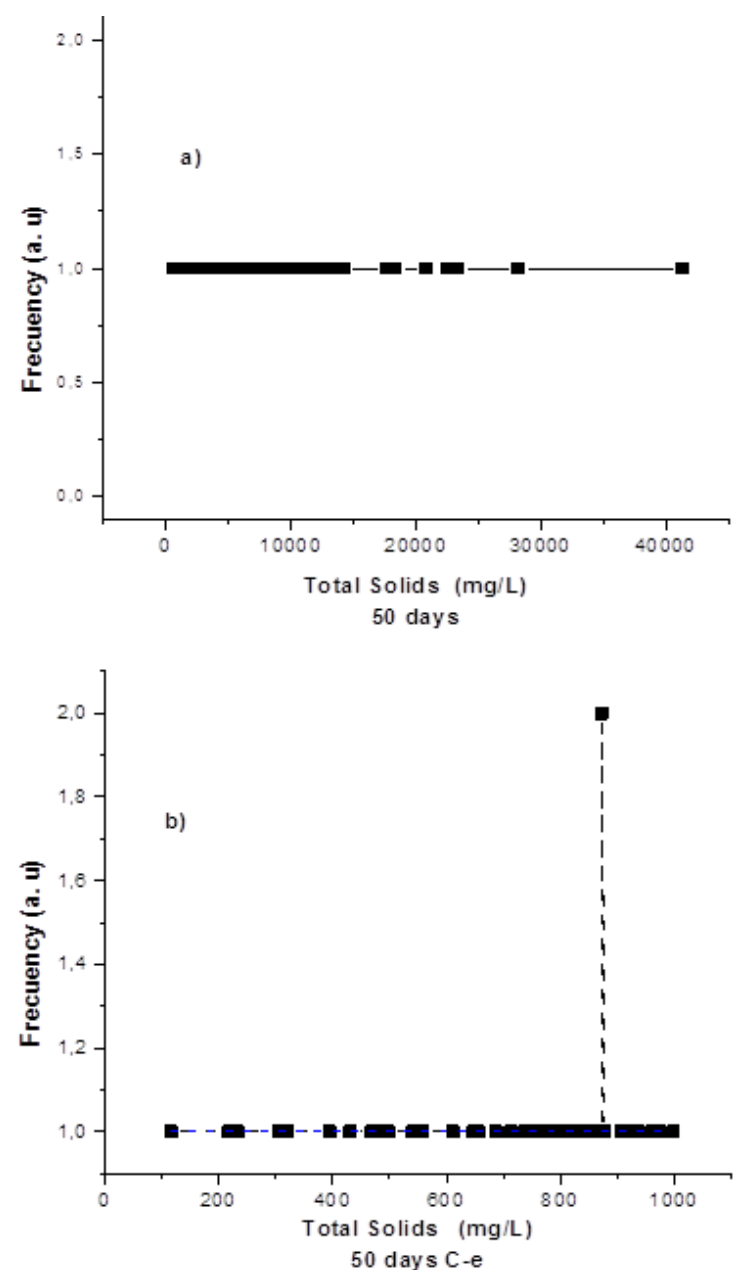

Fig. 5. Graphic (a) shows a linear pattern behaviour in $\mathrm{C}-\mathrm{i}$ in a 50-day period. In contrast to C-e (b), a peak within the range of greater number of readings was registered

The values had their origin in three aspects: the existence of non-digested organic matter, a high concentration of carbonates in this first stage where sedimentation takes place and the first anaerobic digestion process.

Once the initial digestion of $\mathrm{C}-\mathrm{i}$ is completed, the process continues through the subsequent stages to end up in $\mathrm{C}$-e, where the recovered effluent reported the statistical values described in (Table 1); which are described in figure (6b) where the range readings $1619-2215 \mu \mathrm{S} / \mathrm{cm}$ showed three peaks of equal frequency at two, which can be interpreted as fewer chemical reactions triggered by specific microorganisms in C-e.

As observed in $\mathrm{C}-\mathrm{i}$ and $\mathrm{C}-\mathrm{e}$ (Table 1) concentrations, E.C. did not diminish a lot because the psychrophilic process contains Volatile Suspended 

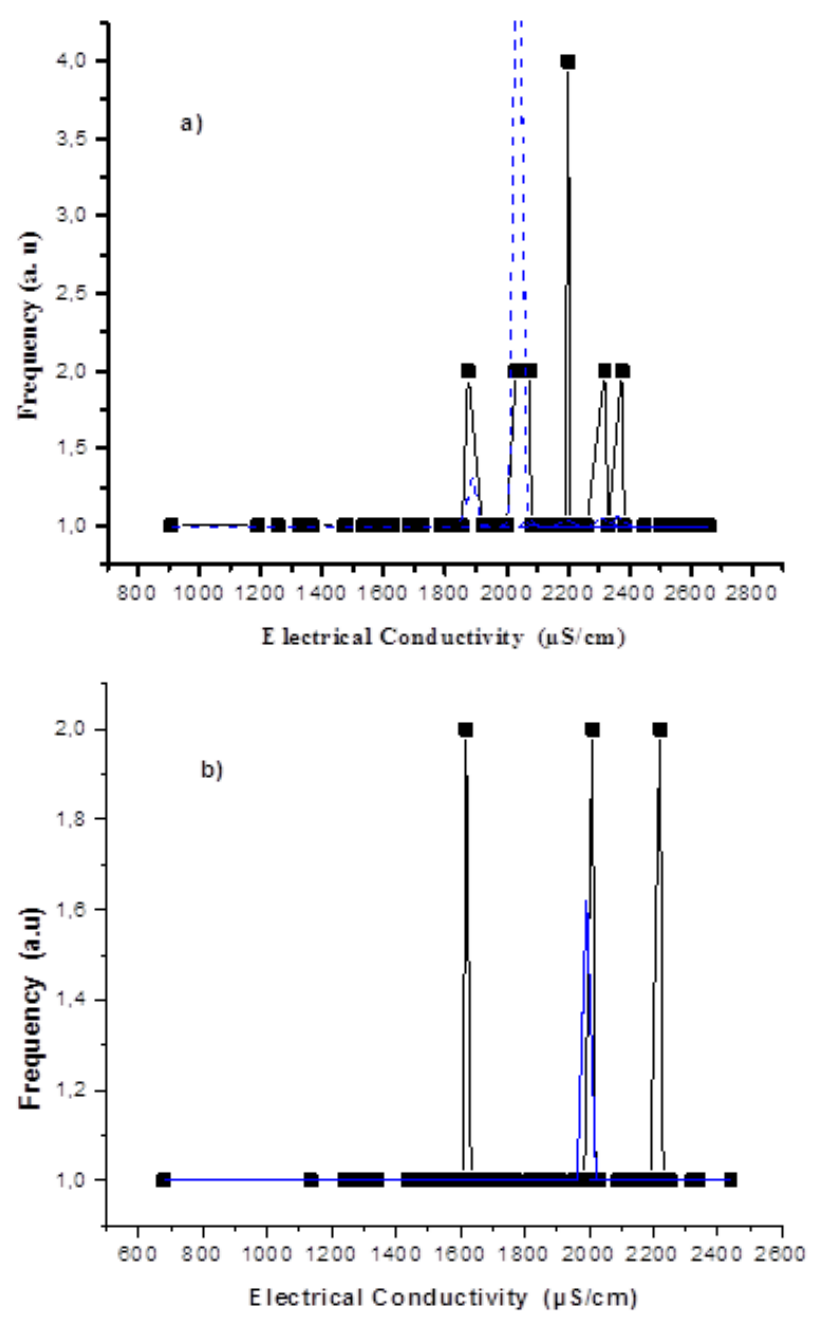

Fig. 6. Whereas E.C. profile of C-i influent in graphic (a) shows a greater number of variations, the $\mathrm{C}$-e effluent suggests that graphic (b) has a fewer number of repetitions

Solids made up by organic matter and its related ions. Thus, these solids are not totally removed provoking effluent turbidity [16]. Nevertheless, the average in $\mathrm{C}$-e is within the values allowed by NOM-CCA/032ECOL/1993 (Table 2).

\section{$3.6 \mathrm{pH}$ Behaviour}

The anaerobic process developed at a psychrophilic temperature of $19.2{ }^{\circ} \mathrm{C}$ in $\mathrm{C}-\mathrm{i}$, favoured the following $\mathrm{pH}$ results at the moment of the experiment (Table 1). These values are explained in detail in graphic (7a), where a neutral $\mathrm{pH}$ is observed with two frequency groups, at 7.5 and the second block in a range between 7.7 and 8.05.

Nonetheless, the biggest amount of readings identified in the profile (7a) is in the range between $7.0 \pm 2.21$ and $7.99 \pm 0.82$, with $\mathrm{pH}$ neutral values, mainly, which allows the nitrification of the wastewater submitted to treatment [20]. The nitrifying bacterial group starts the alkalisation, where every ammonia gram produces an ion nitrate oxidation [13].
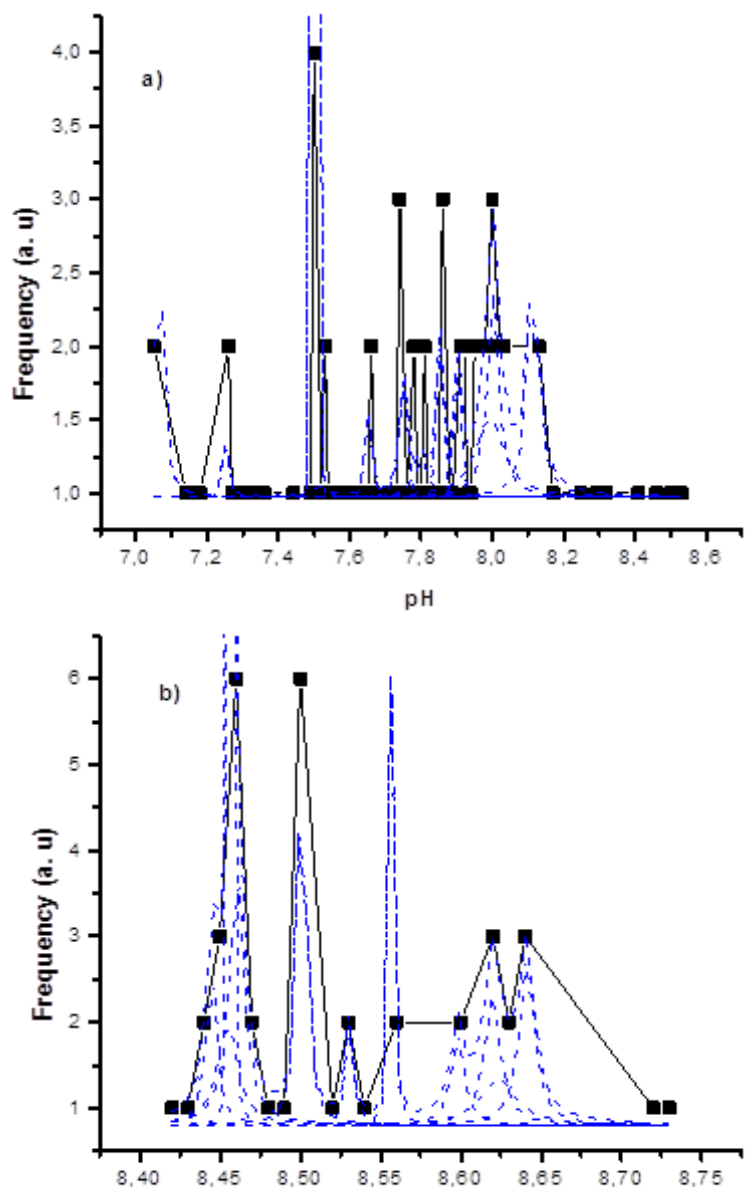

$\mathrm{pH}$

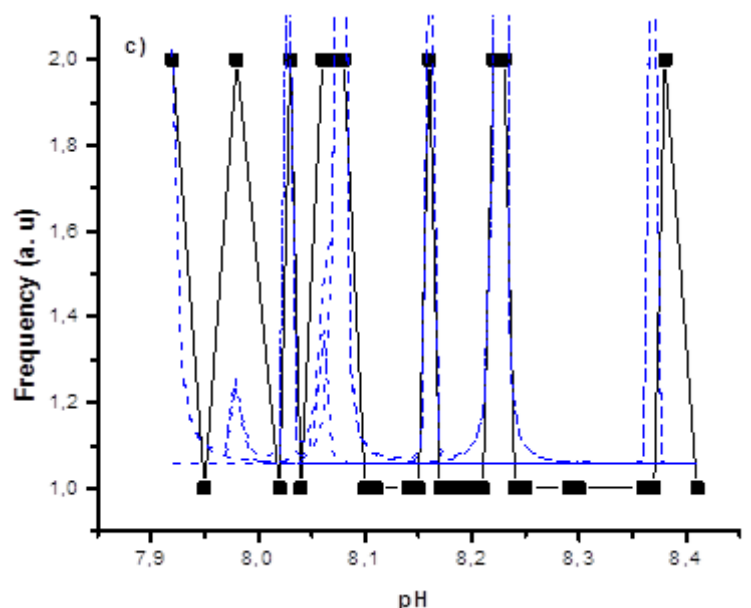

Fig. 7. The graphics show the $\mathrm{pH}$ pattern. Whereas for $\mathrm{C}-\mathrm{i}(\mathrm{a})$, there is a 50-day period, for $\mathrm{C}$-e, the results were analysed in two 25-day periods, each one (b, c) 
However, the referred figure also presents two $\mathrm{pH}$ peaks between $8.00 \pm 0.10$ and $8.11 \pm 1.7$. These values are favourable for the development of the anaerobic process [20], whose carbonated organic matter turns into volatile fat acids and into carbonates [5].

Just as water finishes passing through the compartments, it reaches its last treatment at C-e, where sludge is significantly diminished and water presents changes regarding an effluent free of nondegraded material, at a temperature of $20.1{ }^{\circ} \mathrm{C}$ and an alkaline $\mathrm{pH}$, as reported in (Table 1).

For this purpose, the studied simple was divided into two time periods of 25 days, each one, for its graphical analysis. The first one registered two distributions with a frequency of six in the narrow $\mathrm{pH}$ range between 8.4 and 8.6 as shown in figure (7b), considering the specific values of the process. Moreover, in this range, E. Coli is present [22] in a high volume of fat acids [14], which acts as a reactive that solubilises the sludges and acts as a buffer agent that avoids the $\mathrm{pH}$ drop as a lid to avoid $\mathrm{pH}$ spills [35].

In graphic (7c), the information is completed regarding the second period. The report of steady frequencies no greater than two in the range from 7.95 to 8.40 continuously identified this $\mathrm{pH}$ data as particular records during the process operation. Besides meeting the standardisation that defines the pH permissible limit between 5.5-10.00 (Table 2).

\subsection{Total hardness $\left(\mathrm{CaCO}_{3} \mathrm{mg} / \mathrm{L}\right)$}

The influent injected to $\mathrm{C}-\mathrm{i}$ was submitted to the following system variables: temperature, light absence, $\mathrm{pH}$ and contact with bacterial film. These conditions helped to unchain specific reactions of the process that led to a total hardness $\left(\mathrm{CaCO}_{3}\right)$ as a by-product, and that can be defined as the sum of polyvalent calcium and magnesium cations expressed as calcium carbonate at a $\mathrm{pH}$ base.

These chemical changes contributed to develop an alkaline process that reacts with the cell walls including lipid saponification to solubilise the membrane [35]. Furthermore, high electric conductivity can be found [5] as well as optimal environment for nitrifying the process. This latter generated turbidity that was slightly modified even when $\mathrm{SO}_{4}=\mathrm{CO}_{3}=$ anions and $\mathrm{Ca}^{++}, \mathrm{Mg}^{++}$cations precipitated [18] in (Ci-Ce) influent-effluent.
In $\mathrm{C}-\mathrm{i}$, treated wastewater was statistically analysed and results are exhibited in (Table 1). The lowest result is $(92.61 \mathrm{mg} / \mathrm{L})$ that corresponds to a simple processed after the evening or night rainfall of a day before. This data (Table 1) seen in graphic (8a) exhibits a hardness range between $150-250 \mathrm{mg} / \mathrm{L}$, which includes the greater number of parameter records during the process monitoring in $\mathrm{C}-\mathrm{i}$, and exhibits a peak of $230.11 \mathrm{mg} / \mathrm{L}$ and a two frequency.

Nevertheless, water continued its treatment until reaching $\mathrm{C}$-e for its last process drawing the measures described in (Table 1). These values can be completed with the profile information (8b), and refers an only three frequency located at $207.64 \mathrm{mg} / \mathrm{L}$, as well as two frequencies at two, one at $218.75 \mathrm{mg} / \mathrm{L}$ and the other at $230.11 \mathrm{mg} / \mathrm{L}$.

The first two concentrations mentioned above are found in the range with more readings from
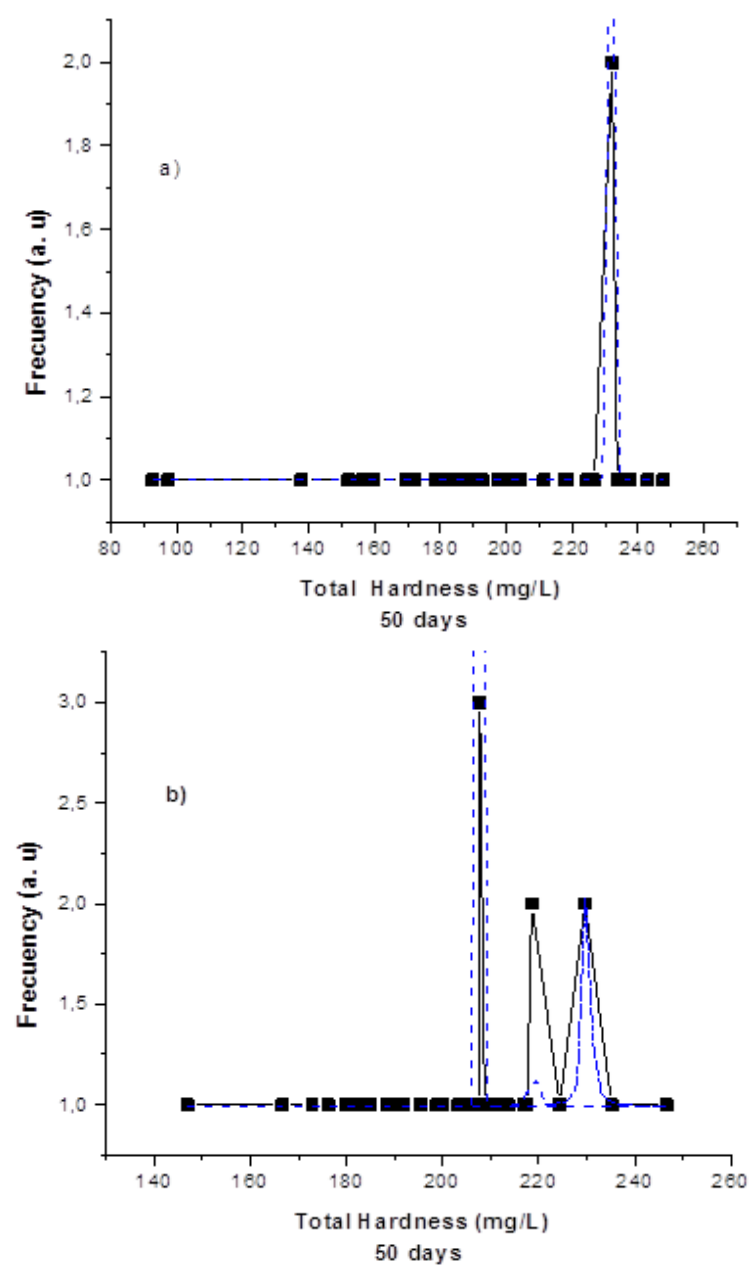

Fig. 8. The graphics show the pattern of total hardness in both chambers. For $\mathrm{C}-\mathrm{i}$ (a) and $\mathrm{C}-\mathrm{e}$ (b), the periods are of 50 days 
$175.00 \mathrm{mg} / \mathrm{L}$ to $218.00 \mathrm{mg} / \mathrm{L}$. Probably these results correspond to the microbiological life cycle stage by which microorganisms flow through the processed water, as well as to the high microbial activity during the sampling.

It must be highlighted that the minimum values in $\mathrm{C}$-e are over the minimum ones in $\mathrm{C}$-i. Even when the rainfall took place one or two days before the monitoring, a stable, steady and specific treatment alkalisation is suggested. Without dramatically modifying the recovered effluent average $(203.23 \mathrm{mg} / \mathrm{L})$, and considering the treated water as slightly hard whose mineralisation neither has a negative impact nor restricts its use for agricultural watering [34].

\section{$3.8 \mathrm{BOD}_{5}$ content $(\mathrm{mg} / \mathrm{L})$}

The average $\mathrm{BOD}_{5}$ concentration in $\mathrm{C}-\mathrm{i}$ influent reported $222.19 \mathrm{mg} / \mathrm{L}$. This fluid continues its path until concluding it at $\mathrm{C}$-e. The reached value was $148.39 \mathrm{mg} / \mathrm{L}$ which represents $33.21 \%$ less than in C-i.

This drop has its origin in the mixed bacterial cultures [42] that live in several layered niches whose related strata [19] in the chambers progressively reduce the $\mathrm{BOD}_{5}$ concentration during digestion [7]. Therefore, the $\mathrm{C}$-e result is within the limit set by the standard for treated water for agricultural watering (Table 2).

\subsection{COD content $(\mathrm{mg} / \mathrm{L})$}

The oxidation for hard organic substances and toxic organic substances for microorganism was undertaken in the influent by oxygen consumption [7]. It is registered a COD concentration of $450.45 \mathrm{mg} / \mathrm{L}$ in $\mathrm{C}-\mathrm{i}$, which is considered as the highest value in the digester chambers. As a result of the mud particles found in treated water [41].

However, the effluent in C-e fell to $434.08 \mathrm{mg} / \mathrm{L}$ in COD when volatile suspended solids are present. The total removal is by $3.64 \%$.

\subsection{Heavy metals}

For this work the influent was obtained from a toilet that works with usable water, and the monitoring of heavy metals had two objectives: process control, due to the fact that its removal is done by precipitated sludge such as sulphites and/or carbonates [12], as well as the verification of the standardisation consulted for treated water (Table 2). Even though, in this study a biological treatment was applied.

The elements were set according to the consulted standards, so that their concentration could be known and, therefore, avoid any toxic effects. If the amounts are high, the effluent use can be reduced for agricultural watering [39, 17].

On this basis naturally and/or anthropogenically polluted metals must be identified and quantified. The first type proceeds from: erosion, fires, lixiviation, volcanic activity and microbial transformation. While the second derives from: industrial remnants, municipal remnants, mining extraction remnants, wastes produced by fusing ferrous minerals, production of fertilizers and pesticides, wastewaters precipitation, fossil fuels burning as well as metal accrual in anoxically environmental niches.

These elements are classified in two types: stimulating such as $\mathrm{Fe}$ or biodegradation inhibitors such as $\mathrm{Cu}, \mathrm{Ni}, \mathrm{Zn}, \mathrm{Cd}, \mathrm{Cr}$ and $\mathrm{Pb}$. In both cases their action is given by: an ionically soluble metal concentration in solution, traced metallic species, amount and distribution of element(s) in biomass inside the digester as well as wastewaters components.

In general, metalloids have an influence on the physicochemical reactions triggered during the anaerobic process. The result is a precipitation of carbonate and hydroxides such as sulphide, except for $\mathrm{Cr}$. These metalloids absorb the solid biomass portion or the inert matter particle, form compounds in solution, and help the growth and development of microorganisms, plants as well as animals. When the biomass is digested, these metalloids take part in biochemical reactions and modify the enzymatic bonds by interrupting their function.

Furthermore, these elements build up $0.1-5 \mathrm{~mm}$ biogranules during methane genesis, where diverse trophic bacterial groups favour granulation starting by bacterial absorption, microbial relations, adhesion to inert matter, inorganic among themselves and/or by physicochemical interactions.

Nonetheless, the following environmental variables are necessary for a granulation: $\mathrm{pH}$, alkalinity, temperature, wastewater composition, reactor hydrodynamics, metallic ion presence, metallic traces, polymers existence and microbiological interactions where every trophic group plays its own role in pollutants degradation and biomass production [24].

\subsubsection{Arsenic (As)}

Element found on the earth's surface, from being inorganically found in subterranean waters 
is considered highly toxic and its presence in atmospheric washouts is due to rainfalls [33].

These precipitations were present at the sampling, and possibly were responsible for a slight increase in $\mathrm{C}-\mathrm{i}$ for the last results observed $[0.0063 \mathrm{mg} / \mathrm{L}]$, with respect to the first reading $[0.0005 \mathrm{mg} / 1]$. Nevertheless, the average value diminished to $[0.0007 \mathrm{mg} / \mathrm{L}]$ in C-e, as a result of its precipitation while passing through the digester [12]. This value is under the permissible limits but does not represent any harmful effect in health (Table 2).

\subsubsection{Cadmium (Cd)}

Metal by-product of the extraction of $\mathrm{Zn}, \mathrm{Pb}$ and $\mathrm{Cu}$ and is commonly used in the metallurgical process and when high amounts of it are unloaded in wastewaters that produces toxic effects in the environment. Traces of this element are found in ore minerals such as greenockite $\mathrm{CdS}$ or otavite $\mathrm{CdCO}_{3}$ It is also used in the production of artificial phosphate fertilisers lodged in soils. It is present in atmospheric emissions by urban remnants burning as well as by fossil fuels and is considered a teratogenic and carcinogenic [32].

For this study, the alkaline conditions of $\mathrm{pH} 8$ [12] favoured a C-influent, and a C-e effluent with a stable concentration $<0.1820 \mathrm{mg} / \mathrm{L}$ for both compartments, meeting the standardised limits (Table 2).

\subsubsection{Cyanide ( $\left.\mathrm{CN}^{-}\right)$}

Monovalent anion that inhibits oxidase action in chemical reactions, provokes interferences in soluble iron and blocks oxygen transport at cell level [24]. This last property has a repercussion on biological treatment processes due to the fact that microorganisms have less $\mathrm{O}_{2}$ available.

In this study the $\mathrm{C}-\mathrm{i}$ influent in $\mathrm{CN}^{-}$, reported an average result $<0.0395 \mathrm{mg} / \mathrm{L}$, which does not affect the depurating process and is lesser than the reference value set by NOM-002-ECOL-1996 of 1.5 $\mathrm{mg} / \mathrm{L}$ for sewage unloading. This value repeats in $\mathrm{C}$-e water and is within the permitted standardized limit (Table 2).

\subsubsection{Copper (Cu)}

Oligoelement found on earth and seawater capable of combining with other compounds. It is considered as a nutrient and seeks to form metal alloys. It has a fungicide and pesticide action and is toxic in soft waters, building up $\mathrm{Cu}^{2+}$ cation [32].

Its determination for $\mathrm{C}-\mathrm{i}$ influent registered a minimum $0.1917 \mathrm{mg} / \mathrm{L}$ and maximum $0.8299 \mathrm{mg} / \mathrm{L}$.
This variation in both values can be due to the amount of metal in the wastewater unloaded to the reactor. This liquid continues up to C-e for its last process, where the $\mathrm{Cu}$ average concentration is of $<0.1240$ $\mathrm{mg} / \mathrm{L}$ in the samplings done. Probably this result comes from the process alkalinity and lime presence [12]. In this case both factors helped the metal fall by keeping enough amounts in the reactions of oxide reduction for microbial enzymatic processes [22]. The results remain within the standardized range (Table 2).

\subsubsection{Mercury $(\mathrm{Hg})$}

Highly toxic element found in: elementary $\mathrm{Hg}$, inorganic mercury $\mathrm{Hg}^{2+}$, and methylmercury $\mathrm{CH}_{3} \mathrm{Hg}_{+}$. Moreover, it can be found in: volcanic gas eruptions, condensed water evaporation as well as anthropogenic springs [33]. It has bioaccumulating and cancerogenic properties for living organisms. This metal poses a risk to health [10], that cannot be removed by biological processes.

As $\mathrm{Hg}$ is part of standards, its $\mathrm{C}-\mathrm{i}$ influent concentration was proved by registering $<0.1240$ $\mathrm{mg} / \mathrm{L}$, whereas the $\mathrm{C}$-e result $<0.0005 \mathrm{mg} / \mathrm{L}$ is under the allowed standard value (Table 2 ). This result does not limit the biological function [24]. Its decrease is probably due to contact with other metals [12] under the digester specific condition for precipitation.

\subsubsection{Nickel (Ni)}

Metal found on the earth's crust in three states: solid, liquid and gas. It builds up deposits in water bodies as well as soil sediments. It is also present in atmospheric gases [33]. It can alter the enzymatic function and structure in reactions, and immediately act in acidogenic groups but slowly in methanogenic bacteria [24].

This element can be observed in remaining from metallurgic and metallic processes, which are unloaded in wastewaters where they should be removed by proper processes. Biological treatments are a good alternative as they removed metal by $99 \%[4,15]$.

When nickel is evaluated in $\mathrm{C}-\mathrm{i}$ wastewater for its treatment, the first concentration $<0.0005 \mathrm{mg} / \mathrm{L}$ increased up to $0.1469 \mathrm{mg} / \mathrm{L}$ in samplings. This could be for the displacement of sediments during rainfall, and/or the chemical reactions at the methanogenic stage of the anaerobic process [24].

Nonetheless, when water finishes its journey through the compartments, it reaches C-e for the 
last process stage. It registers an average value of measurements of $<0.1240 \mathrm{mg} / \mathrm{L}$. This value subtly diminishes with respect to the last $\mathrm{C}-\mathrm{i}$ reading where data was within the permissible standard limit (Table 2). Besides suggest a specific microbial activity that helps eliminating $\mathrm{Ni}$ [15], without any negative phototoxic impacts on the vegetal metabolism that hams its growth [17], nourishments absorption and translocation through different organs [16].

\subsubsection{Lead (Pb)}

Its determination underlies in its character: toxic, bioaccumulating, teratogenic, responsible for intellectual disorders, arterial hypertension, kidneys damage [10]. This metal is found in small amounts over the earth's crust. Its employment in industrial processes: mining, siderurgical, recycling, painting and fuels [32]. It generates highly pollutant emissions, whereas in the anaerobic biodegradation it turns out the methanogenic activity slow but it accelerates acidogenesis [24].

In $\mathrm{C}-\mathrm{i}$, the influent registered a $0.4836 \mathrm{mg} / \mathrm{L}$ maximum concentration, which does not inhibit the treatment process [39], and does not interfere with the sewage unload for this case inside the biodigester according to NOM-002-ECOL-1996.

Once the three processes are carried out, water continues up to $\mathrm{C}$-e where its last depuration exhibited a $<0.2000 \mathrm{mg} / \mathrm{L}$ average concentration of the samplings done. These results could originate from its precipitation in the existing mud [12], meeting the standard without being harmful to population (Table 2).

\subsubsection{Zinc (Zn)}

Abundant trace metal on the Earth's surface, in usable water it forms salts or organic complexes and can be considered as an impurity or a pollutant if it exceeds the necessary concentration in some raw materials [33].

For this study purpose, this metal in C-i influent registered variable concentrations during samplings, minimum at $0.3490 \mathrm{mg} / \mathrm{L}$ and maximum at 4.4836 $\mathrm{mg} / \mathrm{L}$, both within the NOM-002-ECOL-1996 range. This fluctuation can be due to the quality of the WC supplied water and/or the $\mathrm{Zn}$ content consumed on sanitary user's diet.

However, the liquid oscillating data in $\mathrm{C}-\mathrm{i}$ decreases for the $\mathrm{C}$-e effluent, whose $\mathrm{Zn}$ concentration diminished by a $<0.1450 \mathrm{mg} / \mathrm{L}$ constant while the monitoring. This can be as a result of metal precipitation during the alkaline process and microbiological activity, respectively, keeping the concentration within regulated limits (Table 2).

\section{Conclusions}

The process of anaerobic psychrophilic biodegradation induced in the offered digester characterized by simple technology, selfmanagement and low cost, proved to be efficient as well as resilient in terms of treating domestic wastewater specifically for sanitary purposes. The result of processing the effluent in different stages is shown to possess individual conditions that favour a progressive treatment of the same type.

This is observed in the SS, SST and ST contained in the residual water of $\mathrm{C}-\mathrm{i}$, where the high concentrations just as the initial sludge, decreased in quantity, shape and size degrading to a lime found in the C-e effluent. These aspects reflect a satisfactory removal of organic matter during the process, showing the results within the maximum permissible limits of the NOM-001-ECOL-1996 and NOM-CCA/032-ECOL/1993 standards.

The latter was used as a complementary rule, which revision of variables and ranges allowed to increase the margin of safety in the evaluation for the reuse of the effluent obtained.

\section{Acknowledgments}

The authors thank the Centre for Technical Research and Innovation (CIITEC in Spanish) of the National Polytechnic Institute (IPN in Spanish), for allowing the installation of a full-capacity digester within their facilities, and for authorizing the use of equipment and materials belonging to the Environmental Control Laboratory in order to carry out tests, and to the National Council for Science and Technology (CONACYT in Spanish) for granting the first author a scholarship for doctoral studies.

\section{References}

1. APHA, AWWA \& WEF (2012). Standard methods for examination of water and wastewater. 22nd ed. Washington: American Public Health Association, 1360 p.

2. Brauer, H. and Hefni-Omar, M. (1988). Biological elimination of ammonium contained at high concentration in waste water. Bioprocess Engineering, Vol. 3, Issue 2, pp. 51-62.

3. Butarbutar, I., Varianemil, D. and Sanwani, E. (2013). Influence of Variation Dosage of Chemical Reagents in the Turbidity of Overflow from Sedimentation Process at Dewatering Plant of PT. Freeport Indonesia. Procedia Earth and Planetary Science, Vol. 6, pp. 287-294. 
4. Cañizares-Villanueva, R.-O. (2000). Biosorción de metales pesados mediante el uso de biomasa microbiana. Revista Latinoamericana de Microbiología, Vol. 42, pp. 131-143.

5. Cervantes-Zepeda, A. I., Cruz-Colín, M. R., AguilarCorona, R., Castilla-Hernández, P. and Meraz-Rodríguez, M. (2011). Caracterización Fisicoquímica y Microbiológica del agua tratada en un reactor UASB escala piloto. Revista mexicana de ingeniería química, Vol. 10, No. 1, pp. 67-77.

6. Chávez-Porras, Á., Cristancho-Montenegro, D.-L. and Ospina-Granados, É.-A. (2009). Una alternativa limpia para el tratamiento de las aguas residuales galvánicas: revisión bibliográfica. Revista Ingenierías Universidad de Medellin, Vol. 8, No. 14, pp. 39-50.

7. Crites, R. and Tchobanoglous, G. (2000). Tratamiento de aguas residuales en pequeñas poblaciones. Colombia: McGrawHill, pp. 33, 45, 57, 177, 181, 345, 348, 385.

8. Chernicharo, C. A. L. (2006). Post-treatment options for the anaerobic treatment of domestic wastewater. Reviews in Environmental Science and Bio/Technology, Vol. 5, Issue 1, pp. 73-92.

9. Chong, S., Sen, T. K., Kayaalp, A. and Ang, H. (2012). The performance enhancements of upflow anaerobic sludge blanket (UASB) reactors for domestic sludge treatment A State-of-the-art review. Water Research, Vol. 46, Issue 11, pp. 3434-3470. DOI: 10.1016/j.watres.2012.03.066

10. Department of Health (2015). RTK Hazardous Substance Fact Sheets. State of New Jersey. [online] Available at: https://www.nj.gov/health/eoh/rtkweb/documents/fs/1222. pdf [Date accessed 03.02.2020].

11. Del Borghi, A., Gallo, M. and Del Borghi, M. (2009). A survey of life cycle approaches in waste management. The International Journal of Life Cycle Assessment, Vol. 14, Issue 7, pp. 597-610.

12. Eckenfelder Jr., W. (2000). Industrial Water Pollution Control. USA: McGraw-Hill, pp. 138-149.

13. Rodríguez, M. A. E., Bolaños, O. B., Aguirre, J. M. O. and Millán, A. H. (2014). Evaluación de la nitrificación a través de perfiles operacionales en un reactor aerobio. Ingenierías, Vol. XVII, No. 62, pp. 50-62.

14. Feng, L., Yan, Y. and Chen, Ch. (2011). Co-fermentation of waste activated sludge with food waste for short-chain fatty acids production: effect of $\mathrm{pH}$ at ambient temperature. Frontiers of Environmental Science \& Engineering in China, Vol. 5, Issue 4, pp. 623-632. DOI: 10.1007/s11783-011-0334-2.

15. García, N., Villanueva, P., Campos, E. and Velázquez, A. (2012). Análisis de la adsorción como método de pulimiento en el tratamiento de aguas residuales. [online]. Quivera, Vol. 14, Issue 1, pp. 109-129. Available at: http://www.redalyc.org/ articulo.oa?id=40123894007 [Date accessed 03.02.2020].

16. Iñiguez-Covarrubias G. and Camacho-López, A. (2011). Evaluación de un reactor de manto de lodo con flujo ascendente (UASB) con cambios de velocidad de alimentación. Ingeniería Investigación y Tecnología, Vol. 12, No. 2, pp. 199-208.

17. Keser, G. and Buyuk, G. (2011). Effects of Wastewater Irrigation on Chemical and Physical Properties of Petroselinum crispum. Biological Trace Element Research, Vol. 146, Issue 3, pp. 369-375. DOI: 10.1007/s12011-011-9259-7.

18. Kopittke, P. M. and Menzies, N. W. (2005). Control of nutrient solution for studies at high pH. Plant and Soil, Vol. 266, Issue 1-2, pp. 343-354.

19. Lettinga, G. (1995). Anaerobic digestion and wastewater treatment system. Antonie van Leeuwenhoek, Vol. 67, Issue 1, pp. 3-28.
20. Low, E. and Chase, H. (1999). Reducing production of excess biomass during wastewater treatment. Water Research, Vol. 33, Issue 5, pp. 1119-1132.

21. McCleskey, R. B., Nordstrom, D. K., Ryan, J. N. and Ball, J.W. (2012). A new method of calculating electrical conductivity with applications to natural waters. Geochimica et Cosmochimica Acta, Vol. 77, pp. 369-382. DOI: 10.1016/j. gca.2011.10.031.

22. McLaughlin, M. R., Brooks, J. P. and Adeli, A. (2012). Temporal flux spatial dynamics of nutrients, fecal and zoonotic pathogens in anaerobic swine manure lagoon waters. Water Research, Vol. 46, Issue 16, pp. 4949-4960. DOI: 10.1016/j. watres.2012.06.023.

23. McKeown, R.M., Hughes, D., Collins, G., Mahony, T. and O'Flaherty, V. (2012). Low-temperature anaerobic digestion for wastewater treatment. Current Opinion in Biotechnology, Vol. 23, Issue 3, pp. 444-451. DOI: 10.1016/j. copbio.2011.11.025.

24. Mudhoo, A. and Kumar, S. (2013). Effects of heavy metals as stress factors on anaerobic digestion processes and biogas production from biomass. International Journal of Environmental Science and Technology, Vol. 10, Issue 6, pp. 1383-1398. DOI: 10.1007/s13762-012-0167-y.

25. Nelson, M., Pechurkin, N. S., Allen, J. P., Somova, L. A and Gitelson, J. I. (2009). Closed Ecological Systems, Space Life Support and Biospherics. In: Wang, L. K. et al. (eds) Handbook of Environmental Engineering, Vol. 10: Environmental Biotechnology. New York: Humana Press, pp. 517-565.

26. Secretaria de Medio Ambiente y Recursos Naturales (1996). Norma Oficial Mexicana NOM-002. Que establece los límites permisibles de contaminantes en las descargas de aguas residuales a los sistemas de alcantarillado urbano o municipal. [online] Available at: http:/siga.jalisco.gob.mx/Assets/ documentos/normatividad/nom002semarnat1996.htm [Date accessed 03.02.2020].

27. Secretaria de Desarrollo Social (1993). Norma Oficial Mexicana NOM-CCA/032-ECOL/. Que establece los límites máximos permisibles de contaminantes en las aguas residuales de origen urbano o municipal para su disposición mediante riego agrícola. [online] Available at: http://www.paot.org.mx/centro/ ine-semarnat/gacetas/GE28.pdf [Date accessed 03.02.2020].

28. Secretaria de Comercio y Fomento Industrial (2008). Norma Mexicana NMX-AA-003-(1, 2, 3). Aguas residualesMuestreo Norma Mexicana NMX-AA-004-SCFI-2013. Análisis de agua - Determinación de Sólidos sedimentables en Aguas Naturales, Residuales y Residuales Tratadas. [online] Available at: http://www.economia-nmx.gob.mx/normas/nmx/2009/proynmx-aa-003-1-scfi008.pdf [Date accessed 03.02.2020].

29. Secretaria de Comercio y Fomento Industrial (2013). Norma Mexicana NMX-AA-007. Análisis de Agua - Determinación de la Temperatura en Aguas Naturales, Residuales y Residuales Tratadas. [online] Available at: https:// www.imta.gob.mx/cotennser/index.php?option=com [Date accessed 03.02.2020].

30. Secretaria de Comercio y Fomento Industrial (2011). Norma Mexicana NMX-AA-008. Análisis de AguaDeterminación del pH-método de prueba. [online] Available at: http://www.economia-nmx.gob.mx/normas/nmx/2010/nmx-aa008-scfi11.pdf [Date accessed 03.02.2020].

31. Secretaria de Comercio y Fomento Industrial (2000). Norma Mexicana NMX-AA-093- Análisis de AguaDeterminación de la Conductividad Electrolítica. Available at: http://legismex.mty.itesm.mx/normas/aa/aa093-00.pdf 
32. Organización Mundial de la Salud (2006) Guías para la calidad del agua potable PRIMER APÉNDICE A LA TERCERA EDICIÓN Recomendaciones. Genève 1. [online] Available at: https://www.who.int/water_sanitation_health/dwq/gdwq3_es_ fulll_lowsres.pdf?ua $=1$ [Date accessed 03.02.2020].

33. Comité Consultivo Nacional de Normalización de Regulación y Fomento Sanitario (2007). PROYECTO de Norma Oficial Mexicana NOM-XXXX. Agua para uso y consumo humano. Límites máximos permisibles de la calidad del agua, control y vigilancia de los sistemas de abastecimiento. [online] Available at: http://www.economia-nmx.gob.mx/normas/ nmx/2009/proy-nmx-aa-003-1-scfi008.pdf [Date accessed 03.02.2020].

34. Rajesh Banu, J., Uan, D. K., Kaliappan, S. and Yeom, I. T. (2011). Effect of sludge pretreatment on the performance of anaerobic/ anoxic/oxic membrane bioreactor treating domestic wastewater. International Journal of Environmental Science \& Technology, Vol. 8, Issue 2, pp. 281-290. DOI: 10.1007/ BF03326216.

35. Rizvi, H., Ahmad, N., Abbas, F., Bukhari, I. H., Yasar, A., Ali, S., Yasmeen, T. and Riaz, M. (2014). Start-up of UASB reactors treating municipal wastewater and effect of temperature/sludge age and hydraulic retention time (HRT) on its performance. Arabian Journal Chemistry, Vol. 8, Issue 6, pp. 780-786. DOI: 10.1016/j.arabjc.2013.12.016.

36. Sánchez Vargas, A., Gay García, C. and Estrada Porrua, F. (2011). Cambio climático y pobreza en el Distrito Federal. InvestigaSarathai, Y., Koottatep, T. and Morel, A. (2010). Hydraulic characteristics of an anaerobic baffled reactor as onsite wastewater treatment system. Journal of Environmental Sciences, Vol. 22, No. 9, pp. 1319-1326. DOI: 10.1016/S10010742(09)60257-6.

37. SEMARNAT, SAGARPA, FIRCO (2010). Especificaciones Técnicas para el Diseño y Construcción de Biodigestores en México. México Disponible en: Documento Especificaciones Técnicas VF - Proyecto de Energía__proyectodeenergiarenovable.com/.../Biodigestor/ Especificaciones. [online] Available at: http://biblioteca. semarnat.gob.mx/janium/Documentos/Ciga/libros2009/ CD001057.pdf [Date accessed 03.02.2020].

38. Sosa-Rodríguez, F. S. (2012). El futuro de la disponibilidad del agua en México y las medidas de adaptación utilizadas en el contexto internacional. Revista Internacional de Ciencias Sociales y Humanidades, SOCIOTAM, Vol. 12, No. 2 , pp. $165-187$.

39. Van Haandel, A., Kato, M.T., Cavalcanti, P. F. F and Florencio, L. (2006). Anaerobic reactor design concepts for treatment of domestic wastewater. Reviews in Environmental Science and Bio/Technology, Vol. 5, Issue 1, pp. 21-38. DOI: 10.1007/s11157-005-4888-y.

40. Wang, L. K. and Shammas, N. K. (2010) Sequencing Batch Reactor Technology. In: Wang, L. K. et al. (eds). Handbook of Environmental Engineering, Vol. 10: Environmental Biotechnology. Totowa, NJ: Humana Press, pp. 721-747. DOI: 10.1007/978-1-60327-140-0_15.

41. Yi, H., Han, Yu. and Zhuo, Y. (2013). Effect of combined pretreatment of waste activated sludge for anaerobic digestion process. Procedia Environmental Sciences, Vol. 18, pp. 716-721. DOI: 10.1016/j.proenv.2013.04.097.

\section{Authors}

Sánchez-Góngora María-Antonieta

Escuela Superior de Ingeniería Mecánica y Eléctrica del Instituto Politécnico Nacional (ESIME-IPN), Mexico City, México

E-mail: mariaantonieta_gongora@yahoo.com.mx

\section{Peón-Escalante Ignacio-Enrique}

Escuela Superior de Ingeniería Mecánica y Eléctrica del Instituto Politécnico Nacional (ESIME-IPN), Mexico City, México

$$
\text { E-mail: ignaciopeon@gmail.com }
$$

\section{Cardona-Juárez Teresita}

Centro de Investigación e Innovación Tecnológica del Instituto Politécnico Nacional (CIITEC-IPN), Mexico City, México

E-mail: sanfer_73@yahoo.com.mx

\section{Ortega-Arroyo Lesli}

Escuela Superior de Ingeniería Mecánica y Eléctrica del Instituto Politécnico Nacional (ESIME-IPN), Mexico City, México

E-mail: jvales_55@yahoo.com.mx

\section{Castaño Víctor $M$.}

Centro de Física Aplicada y Tecnología Avanzada, Universidad Nacional Autónoma de México, Mexico City, México

E-mail:meneses@unam.mx

\section{Авторы}

\section{Санчез-Гонгора Мария-Антуанета}

Высшая школа машиностроения и электротехники Национального политехнического института Мексики, Мехико, Мексика

E-mail: mariaantonieta_gongora@yahoo.com.mx

\section{Пеон-Эскаланте Игнасио-Энрике}

Высшая школа машиностроения и электротехники Национального политехнического института Мексики, Мехико, Мексика

E-mail: ignaciopeon@gmail.com

\section{Кардона-Хуарез Терезита}

Центр исследования и инновационных технологий, Мехико, Мексика

E-mail: sanfer_73@yahoo.com.mx

\section{Ортега-Арройо Лесли}

Высшая школа машиностроения и электротехники Национального политехнического института Мексики, Мехико, Мексика

E-mail: jvales_55@yahoo.com.mx

\section{Кастано Виктор М.}

Центр прикладной физики и передовых технологий, Национальный автономный университет Мексики, Мехико, Мексика

E-mail: meneses@unam.mx 